\title{
Establishing a College Archives: Possibilities and Priorities
}

\begin{abstract}
Because the job of establishing a college archives often falls to librarians or historians who have had little formal training in archival work, some guidelines are useful. The author discusses how an archives is usually created, ways of publicizing the archivist's activity, and the role and composition of a faculty-staff committee. The second half of the article highlights services the archivist can offer to students, faculty, and administration, including creation of subject and biographical files, collection of faculty and institutional publications, development of an iconographic file, collection and use of memorabilia, and establishment of an oral history program.
\end{abstract}

I NCREASINGLY COLLEGE AND UNIVERSITY LIBRARIES must cope with the availability and demand for nonprint material for instructional use, research, and recreation. Some institutions have met the challenge by establishing separate departmental, divisional, or college libraries within the multiversity. Others have created special learning centers, archives, and recording libraries to handle nonbook material, while still others have centralized the entire operation under the direction of the library with specific departments to handle these specialized needs. In nearly all these cases, the professional librarian has been the person who is charged with the responsibility for developing a viable program, but he has often not had the necessary training in graduate school. Once on the job he may not be given adequate room for innovation or sufficient direction

Nicholas C. Burckel is director, University Archives, University of Wisconsin-Parkside. An earlier version of this article was presented at a conference sponsored by the State Historical Society of Wisconsin, March 29-30, 1973. and budget support to develop a program.

Archivists in particular face that problem. They do not receive an academic degree or certification in preparation for their job, and often their education in history or library science does not equip them to establish a college archives. The best that a potential archivist can hope for is an occasional course in library school which not only focuses on manuscripts and special collections, but on archives generally. ${ }^{1}$ Lacking formal preparation, a librarian who is appointed college archivist must turn to the literature of the field to find some guidance. Unfortunately, relevant information is difficult to find: library journals traditionally eschew archival articles and the American Archivist's articles on college archives are frequently no more than institutional case studies. ${ }^{2}$ The new archivist, therefore, confronts his job with few guidelines or suggestions.

In an effort to establish a college or university archives, the archivist must realize that his own conception of the value of an archives may not necessarily 
correspond with the values perceived by those whom he must serve. The Pyrrhic purist, in defining too narrowly the archivist's purview, succeeds only in diminishing his influence on the campus. Therefore, the archivist's role must be both one of educating the academic community about the nature of an archives and one of accommodating administrators' and students' preconceptions of an archives. $^{3}$ In performing that dual role, the archivist must use his imagination, his budget, and his personality to maximize the importance of the archives in the minds of administrators, faculty, and students. A survey of possible options for publicizing and promoting use of a college archives suggests the variety of approaches available. For purposes of discussion, they can be broadly categorized as personnel and service.

\section{Position of ARChives \\ in a College Administration}

The staffing of the archives and its place in the organization of the college are perhaps the most important determinants of how successful it will be. In most cases, this has been determined by the administration before the archivist is hired. This does not necessarily mean that it cannot be changed in the future, but it is more difficult both because of the necessary red tape involved in any administrative reorganization and because of the inertia of the system, once operative.

The place of an archives in the overall structure of the college may be important less from a budgeting or decision-making point of view than from the need for direct access to key administrators from the chancellor or president on down. If this can be accomplished, even if the salary is not commensurate with the rank or title, then half the battle has been won. Archivists usually function either in an administrative support capacity under the su- pervision of the chancellor or vice-president for university relations or, frequently, in an instructional support capacity under the supervision of the director of libraries and special collections. ${ }^{4}$ Either position has its advantages and disadvantages. In the former case, the archivist is on an equal footing with other campus administrators and may have more success in persuading reluctant directors and deans to relinquish their hold on noncurrent files. What is an asset in dealing with administrators may, however, be a liability with faculty or students. If, for instance, faculties view the transfer of their records as an invitation to the archivist to cull the collection and report to his supervisor, then he is unlikely to get the professor's complete record. This is even more true in dealing with student groups and in using the new techniques of oral history. What professor would be willing to give his unvarnished opinion of university policy and administrators if he did not feel assured of the confidentiality of his remarks? In these instances, the archivist who is less closely identified with the administration and more a part of the college library would undoubtedly enjoy more success. ${ }^{5}$

Often, establishment of an archives derives from administrative mandate rather than from specific faculty or regent legislation. In most institutions the boards of trustees or regents may not call for the creation of an archives, but an active and alert faculty government may recommend it to the administration. If the archives is established at the behest of the faculty, then this fact can be used to emphasize broadly based support. Alternatively, if the archives is created by the administration, that fact should likewise be used to indicate high-level administrative recognition of the need for an archives. Either tack can be taken in prodding reluctant administrators and faculty to turn over 
their records before retiring, changing offices, or leaving the campus.

\section{Publicizing the ARCHIVES}

After establishment of an archives and appointment of the archivist, the job of publicizing the new office should begin immediately. Frequently the public information bureau or student newspaper informs the campus of newly created offices and their services. This is the first and most obvious method of introducing the archivist to the campus community and of explaining his role to the widest possible audience. Another method would be a letter of introduction and explanation from the chancellor, president, or library director to the academic staff. Whether written by the chancellor or some other important administrator, this letter can be of great help in publicizing the role of the archivist on campus.

No matter what the format of such a letter or memorandum, it should contain certain information designated to clarify the archivist's position, general duties, educational background, professional experience, and any other information which will make his case a strong and convincing one. The letter should be brief, allowing the archivist room to discuss relevant details in person at a later date with each departmental chairman or divisional dean.

After the chancellor or librarian has sent a letter of introduction to faculty and administrators, the archivist should make personal courtesy calls. At these meetings he must be prepared to sell his services to the administrators and to allay any fears they may have regarding the loss, damage, or violation of confidentiality of their records. The archivist will have to determine his policies in advance so that he will be able to establish a consistent procedure for all departments. If possible he should survey the records of each office he visits and procure any background information that will help him understand its function and history. Some offices may have departmental histories which not only trace the development of the department, but also provide information about the composition of the staff and their respective positions over the years. If such information is unavailable in this form, then the archivist can frequently obtain the same information through accreditation reports or old university catalogs. ${ }^{6}$

\section{ARchives Committee}

Although its members are not technically part of the staff, an archives committee can be a valuable tool in educating faculty, students, and administrators to the role of an archives. This advisory committee should include the archivist ex officio and representatives from four areas of the university: (1) business, (2) historical, (3) legal, and (4) administrative. The reason for each of these is fairly obvious. Since financial records of the college will eventually be transferred to the archives, it is important that a qualified member of the committee judge which records may later be needed for income tax data, employment record verification, and budget review. Although the archivist is often a trained historian, it is, nevertheless, good to have a faculty representative, preferably from the history discipline and with a background in United States history, to act on behalf of researchers and social scientists who use the archives. Third, some sort of legal representative should be included to give advice regarding the archivist's responsibilities to preserve the confidentiality of certain files, and to interpret the laws concerning the records of the institution (federal, state, or university). Finally, because the archives may be funded through the central administration or because it serves as a major support function for administrators, there should be an administrator on the 
committee who can speak with authority for the staff. ${ }^{7}$

In addition to these four members, the director of libraries would guarantee his stake in the successful development of an archival program. This is especially important when the archives is an integral part, physically and administratively, of the library system. Since a sizable portion of student records will eventually be transferred to the archives, the registrar or director of admissions whose offices generate these records might be included on the committee. In the event university policy permits student representatives on faculty and administrative committees, then the student government should be asked to furnish a representative. A student on the committee would not seriously jeopardize the confidentiality of nonpublic university material, and he might serve to introduce the archivist to the students.

The value of a committee, no matter what its composition, is that it increases the visibility of the archivist to all segments of the university community. Especially where the archivist does not have an academic-administrative appointment, the committee can publicize the archives and give it respectability on the campus. If appeals to faculty and staff can be drafted over the signature of a broadly based committee, the archivist's job will be made easier.

\section{A Service-Oriented Archives}

All of these methods of publicizing the archives to faculty, students, and administrators relate to personnel policies: appointment of the archivist, courtesy calls on academic staff, and creation of an archives advisory committee. But what are the services an archives can offer that might be used to educate and serve the campus community? Services might include establishing and maintaining an extensive records management program and such diverse collec- tions as institutional publications, subject and biographical files, faculty publications, as well as iconographic material, memorabilia, and oral history.

The archivist's first obligation, of course, is to preserve all significant noncurrent records of the university. That includes every type of record: budget, financial, student, faculty, and administrative. Beyond this the amount of collateral work that can be performed is dependent on staff and budget. Many activities performed by the news or public information service, the library, the registrar's office, or admissions office, can as easily be performed by the archives. This is especially true where these other offices are understaffed or cramped for space, as is often the case at an older institution. Many of these services may be necessary, for as the archives comes to be known for these collateral resources, its more fundamental purpose of collecting historically significant records will be better appreciated. But in extending these services, the archivist should neither lose sight of his primary obligation of preserving important noncurrent records nor permit his office to become a dumping ground for inconsequential material.

In the case of the offices of the registrar, admissions, student affairs, payroll, and bursar, the archivist can provide a valuable service as a records manager. These offices generate a substantial number of forms which vary in value from short-term items, such as requisitions or interoffice memos, to permanently valuable student transcripts or budget records. The problem of these offices is one of storage space for important but infrequently used records. A mutually approved records disposal schedule should satisfy the needs of the individual offices for occasional reference work and free them of records which occupy prime office file and storage space. Such a records management program empha- 
sizes cost savings and internal administrative services which a comprehensive college archives can provide. ${ }^{8}$

\section{Vertical Files}

If the archives is to be a clearinghouse for all university-related activities, then the possibilities for a research and resource center reflecting all aspects of the college are great indeed. A college is known to the public mainly through the printed word, often by its own publications, including student newspapers, yearbooks, catalogs, timetables, brochures, conference proceedings, colloquia, bulletins, and alumni newsletters. Internally, these publications provide valuable information for those new to a specific job or interested in the history of the institution, the quality of its work, and the variety of its undertakings. For them, boxes of manuscript materials and volumes of budget records are overkill. But the publications will often be the key to the entire college, the tip of the iceberg. Soliciting, collecting, and maintaining a complete set of all publications supported by or related to the college puts the archivist in contact with most units on campus. The file can serve as reference for the activities of the campus, provide background on programs, and supply information to the press for news releases. Naturally as the collection grows older it develops historical importance as one gauge of the university's growth and development.

Closely associated with a publication file would be a subject file of clip sheets or newspaper clippings. Some large universities have a news service or office of public information which collects all newspaper, magazine, and periodical articles relating to the university. In some cases the athletic department maintains its own sports file. Still other colleges subscribe to a state or regional news clipping service. The archivist should arrange with the offices which handle these files to draft a disposal schedule in which the clippings would be transferred to the archives periodically. The offices originally responsible for the records should, of course, have access to the clippings at any time. Once the news items lose their current value, they become historically important for dating a speech, explaining a situation, or providing information for a commemorative event. For that reason they should be kept in the archives along with other items of enduring value. This clipping file, in fact, can form the nucleus of a major subject file. By including mimeograph material and internal publications, the subject file can become a valuable resource to the university. As people begin to use these materials, they will remember the archives and may use its other collections to find valuable historical information.

In conjunction with the subject file, or separate from it, is a biographical file which would include information on faculty, administration, and students. Sometimes biographical information can be solicited directly from faculty or staff in the form of a questionnaire. This has the advantage of standardizing the information on each person.

Of importance in documenting the achievements of faculty and administration is an author or faculty publications file. Libraries occasionally maintain a faculty publications file, but these are often incomplete because they include only books. A good working arrangement with the other librarians might call for the library to acquire all books published by the faculty and for the archives to collect all articles and published papers. Usually here the archivist can count on the cooperation of the faculty. He can send a form letter to the faculty asking for reprints, or at least for the correct bibliographical citations. After initial solicitation of the faculty, the archivist should circulate 
a similar form semiannually, or obtain a list of new faculty from the dean's office, departmental chairperson, or the college catalog. At a medium-sized or smaller college, the archivist might solicit faculty publications on a personto-person basis. Personalization assures good public relations between the archives and the rest of the academic community and introduces the archivist to all segments of the faculty. It also serves to encourage faculty use of the archives for its intended function-a source of reliable historical data.

\section{NoNPRinT FiLES}

Increasingly important in a multimedia world is nonwritten communication including iconography and video and sound tape recordings. An iconographic or photo collection is of importance not only for news releases or articles, but also for future research on the growth of the college or the biography of a particular faculty member or administrator. The best method of acquiring a photograph file, while at the same time publicizing the archives, is to contact the yearbook or student newspaper staff at the end of each year. The news service may be willing to provide photographs as well. Sometimes local newspapers have photos from previous features on the campus or its activities and personalities. If the archivist assures local newspaper editors that they are welcome to use his own photograph collection, they may be willing to turn over their old photographs to him, especially those of building construction now completed, of buildings no longer standing, of faculty who have died or retired, or of students who have graduated.

Sound and videotape recordings are a valuable record of college activities. Often panel discussions of eminent people, lectures by visiting professors or celebrities, recitals of different musical and choral aggregations, and stage productions flesh out the history of a university. They also provide a record of many important activities that may not be available otherwise. In the event no one records important activities or events on campus, the archives should attempt to do so. However, with a limited budget this is impractical and other projects should have priority. To save time and money the archivist might ask the audiovisual department to supply the sponsoring agency with a tape recorder and charge the archives for the tape. Someone sponsoring the event could then record the activity and send the tape to the archives. Such records are doubly valuable, in fact. They are both the proper domain of archives, and their popular appeal will draw students and faculty to the archives as a source of historical information.

The most amorphous category of archival material is memorabilia. Awards, trophies, and citations given to the college, or to an administrator as representative of the university, are obvious examples of memorabilia. Other items of campus interest in this category include alumni scrapbooks, ground breaking shovels, student dance programs, something from a destroyed building, or relics of student traditions and activities. Though these are perhaps more the stuff of museums, their deposit in the archives will publicize the archives and eventually draw attention to its more important collections. The variety of this material makes classification difficult and storage nearly impossible. Yet these handicaps should not deter the archivist from actively soliciting memorabilia. Memorabilia is seldom of much historical importance in itself but is frequently the only tangible, threedimensional representation of a bygone period. It is often eye-catching and makes an attractive display of the university's history. The archivist can serve the university by preserving the material and can assist in arranging displays of 
the university's past when called upon to do so for open houses, centennials, commemorations, and reunions.

\section{Oral History}

A final dimension to an all-inclusive archival program is an oral history project. The value of some form of oral history has been proven by Columbia University and the various presidential libraries. Yet the costs of such a project should be well understood before implementation. Even on a modest budget, however, the archivist can undertake a limited project that might well complement his own collections. Where cost is a consideration, the interviews need not be transcribed immediately, especially since they will seldom be available for research use without time restrictions. Recording the interviews before key people leave campus should have a higher priority than eventual transcriptions. These interviews are valuable because they supplement the written record and may be the only autobiographical record a busy professor or administrator leaves. As much as any service the archivist provides, an oral history project which asks the right questions of the right people can be of great value. ${ }^{9}$

\section{SUMMARY}

This cursory examination of the variety of archival material and the different types of services an archives can render should not imply that each activity is of equal value. The heart of an archives is its manuscript and administrative files. Papers of faculty and staff are unique whereas publications may be found elsewhere. Therefore, papers of key administrators and prom- inent faculty are of much greater importance than biographical, clipping, or subject files. Scholars will seldom come to the archives in search of publications or memorabilia. They are usually interested in the manuscripts of individuals, in records of various organizations, or in administrative papers that show how decisions were made, who made them, and what the lines of responsibility were. This is the stuff of which biographies, institutional studies, and college histories are written.

Auxiliary services can be emphasized, depending on the size of the staff, age and size of the institution, physical space available, and the energy of the archivist. Records management and retention of vital records are services to offices that generate the records and may be a necessary part of the operation of a college archives, but they should not take precedence over processing archival acquisitions. Like the maintenance of a faculty author file or newspaper file, records management may be necessary to win support for the archives within the administration, to establish good public relations with other departments or divisions, and to establish credibility and worth in the eyes of budget officers.

The individual priorities must be set by the archivist to fit his specific needs, but administrative and faculty files should head his list. Securing and preserving historically important material must nevertheless be combined with a level-headed sense of service to the needs of the academic community. Too rigidly restricting the role of a university archivist reduces his value to the academic community and possibly jeopardizes his job as well!

\section{REFERENCES}

1. Although the Society of American Archivists neither endorses nor accredits courses in archives, its Committee on Education and Professional Development has published a di- rectory, Education Directory: Careers and Courses in Archival Administration (Ann Arbor: The Society of American Archivists, 1973). Twelve universities in the United 
States offer multiple courses on archives; an additional twenty colleges or universities in the United States and Canada offer single courses. These courses are fairly evenly divided between history departments and library schools. One of the six institutes described in the directory deals specifically with college and university archives: an annual summer workshop at Case Western Reserve University.

2. A survey of articles included in "College and University Archives: A Select Bibliography," American Archivist 37:67-72 (Jan. 1974) reflects the emphasis on individual archival institutions. This annotated bibliography of articles and books is the most recent available published source of scholarly literature on college and university archives. Although several articles, reviews, and books on archives are regularly listed in Library Literature, there is a paucity of articles on college archives, and most of these deal with technical areas of classification and retrieval. The most recent issue of Library Trends to deal comprehensively with archives was published in January 1957 and edited by R. W. G. Vail. Various technical aspects of a college archival operation, including a comparison between different methods of classification and control between librarians and archivists, is presented in Proceedings of the Conference on Archival Administration for Small Universities, Colleges and Junior Colleges (University of Illinois Graduate School of Library Science, Occasional Papers No. 88, Oct. 1967). Another useful source for the technical aspects of appraisal, arrangement, and availability of archival material is Woodrow W. Wasson, "Organizing and Administering a University Archives," College \& Research Libraries 29:109-16 (March 1968). A brief overview may be found in Thomas E. Blantz, CSC, "The Librarian as Archivist," Catholic Library World 46:14-16 (July-August 1974).

3. This idea has been a popular theme of the College and University Archives session at recent annual meetings of the Society of American Archivists. The thirty-sixth annual meeting (October 31-November 3, 1972) included a session entitled "Justifying the College and University Archives in the 1970 's," dealing primarily with the archivist's increased responsibilities in a period of fiscal restraint. "The Role of College and University Archives: Dimensions and Directions," a session at the thirty-eighth annual meeting (October 1-4, 1974), explored new uses of traditional sources, new methods of documentation, and new services which librarians and archivists can offer.
4. Committee on College and University Archives, College and University Archives in the U.S. and Canada (Ann Arbor: The Society of American Archivists, 1972) is an updated directory of the 1966 survey. The directory is based on a summary of data solicited through nearly 1,400 survey questionnaires of which over 850 were completed and returned. One of the questions dealt specifically with the place of an archives in the table of the institution's organization. Not surprisingly, more than twice as many were listed as reporting to the library than to all other administrative units combined. Other categories included chancellor's or president's office, vice-president for public relations, vice-president for administration, and the department of history.

5. Maynard J. Brichford, "University Archives: Relationships with Faculty," American Archivist 34:173-81 (April 1971); Herbert Finch, "The Problem of Confidentiality in a College Archives," American Archivist 31: 239-41 (July 1968); Walter Rundell, Jr., "Personal Data from University Archives," American Archivist 34:183-88 (April 1971).

6. This approach of soliciting departmental histories was successfully followed in compiling one of the pioneer university histories, Merle Curti and Vernon Carstensen, The University of Wisconsin: A History, 1848-1925, 2v. (Madison: Univ. of Wisconsin Pr., 1949, 1974). These then became one of the first accessions when the archives was formally created; see series $0 / 5 / 11$ in University of Wisconsin Archives, Madison, Wisconsin.

7. The "Laws and Regulations of the University of Wisconsin," for instance, provide for the creation of an Archives Committee. On the Madison campus, faculty legislation spells out exactly who serves on that committee: "the University archivist, the secretary of the faculty, the vice-president for business affairs, the chairman of the Library Committee, the director of University $\mathrm{Li}$ braries, the director of the State Historical Society, and three additional members of the faculty appointed by the Chancellor," Sec. 24.03 "Laws and Regulations of the University of Wisconsin, 1969."

8. Clifford K. Shipton, "The Reference Use of Archives," in Rolland E. Stevens, ed., University Archives (Champaign: Illini Union Bookstore, 1965), p.68-81; Helen L. Chatfield, "Records Management in the Administration of College and University Archives," American Archivist 31:243-45 (July 1968); William F. Schmidt and Sarah J. Wilson, "A Practical Approach to University Records Management," American Archivist 31:247- 
64 (July 1968); William Saffady, "A University Archives and Records Management Program: Some Operational Guidelines," College \& Research Libraries 35:204-10 (May 1974); G. W. Cornell, "The College Archive: A Study in Administration" (Ph.D. dissertation, The Ohio State University, 1968), p.111-76; North Carolina State Department of Archives and History, College and University Records Retention and Disposition Schedule (Raleigh: State Department of Archives and History, 1964).

9. William W. Moss, Oral History Program Manual (New York: Praeger, 1973) is worth reading, even though the book reflects the type of funding the author has en- joyed during his work on the John F. Kennedy Oral History Project. Although it focuses on California, there is much valuable information in Richard D. Curtiss, Gary L. Shumway, and Shirley E. Stephenson, eds., A Guide for Oral History Programs (Fullerton: California State Univ., 1973). Different aspects of oral history, although not confined to college programs, are discussed in four articles in American Archivist 28:53-83 (January 1965). Unfortunately, there exist little hard data on cost and time for transcribing interviews in oral history programs which supplement a larger archival operation not primarily concerned with oral history. 